\title{
PULMONARY TUBERCULOSIS AMONG MEN OVER FORTY
}

\author{
By CECILY M. TINKER* \\ Late Prophit Scholar, Royal College of Physicians, London
}

(With 2 Figures in the Text)

\section{INTRODUCTION}

For some years, persons interested in tuberculosis have been concerned about the high notification and death-rates persisting in middle-aged and elderly men (Figs. 1, 2; Logan \& Benjamin, 1957), for whereas death-rates showed a steady

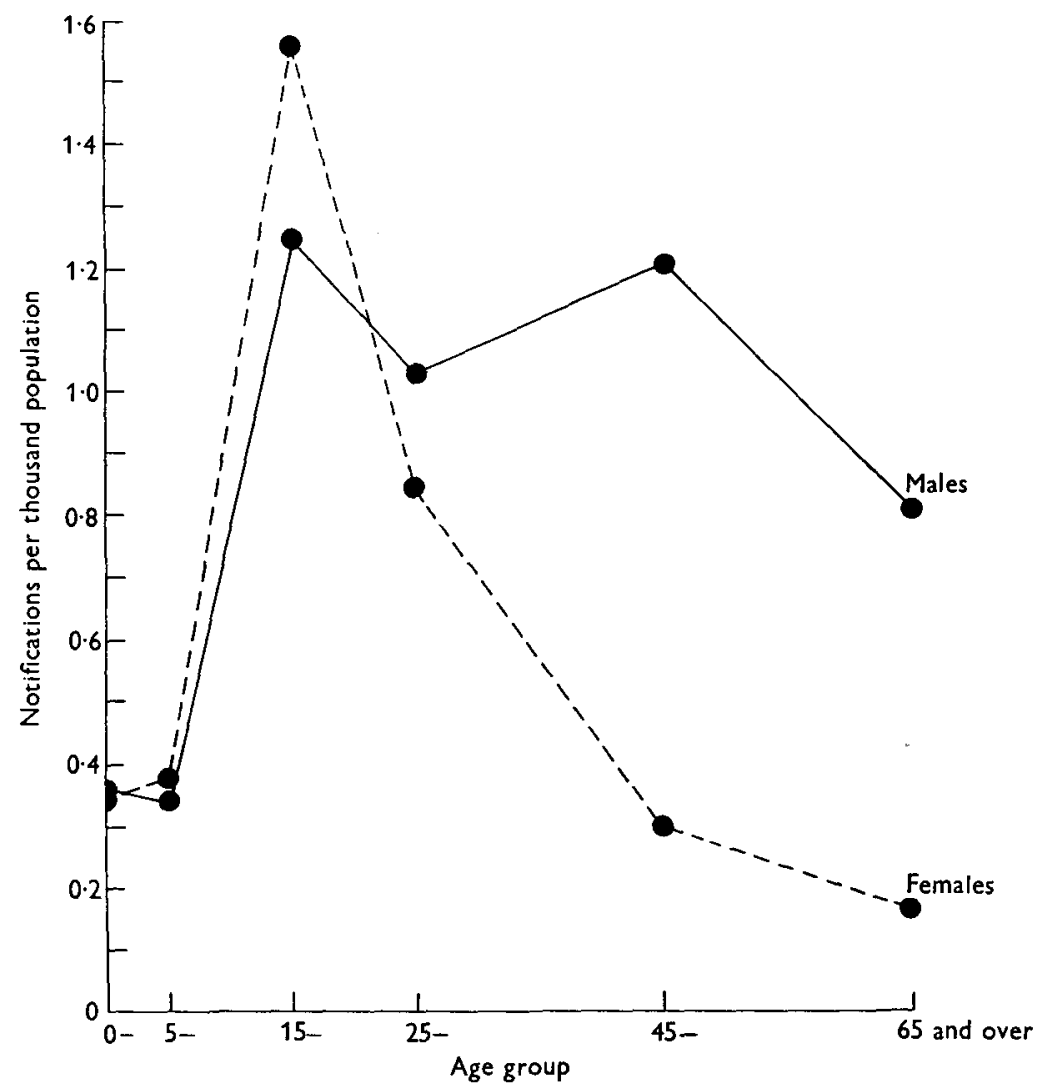

Fig. 1. Notification rates for respiratory tuberculosis, England and Wales, 1955.

decline at ages under 65, no such improvement was evident in the older age groups, and notifications for men over 45 showed a decline of only $1 \%$ between the years 1952-56 (Ministry of Health, 1958).

Tuberculosis mortality rates recorded in the Registrar-General's Decennial

* Present address: Postgraduate Medical School, Hammersmith, London, W. 12. 
Supplements show that for England and Wales in 1851-60 the peak mortality for males from pulmonary tuberculosis (5054 per million) occurred between the ages of 20 and 25 , while the peak mortality for females (4583 per million) occurred between the ages of $25-34$. The mortality rate for men over 65 was less than half this young adult peak (2394 per million). Over the past 100 years the peak of mortality for males in England and Wales has moved steadily from young adult life to older age groups, and since 1950 the maximum mortality has occurred at

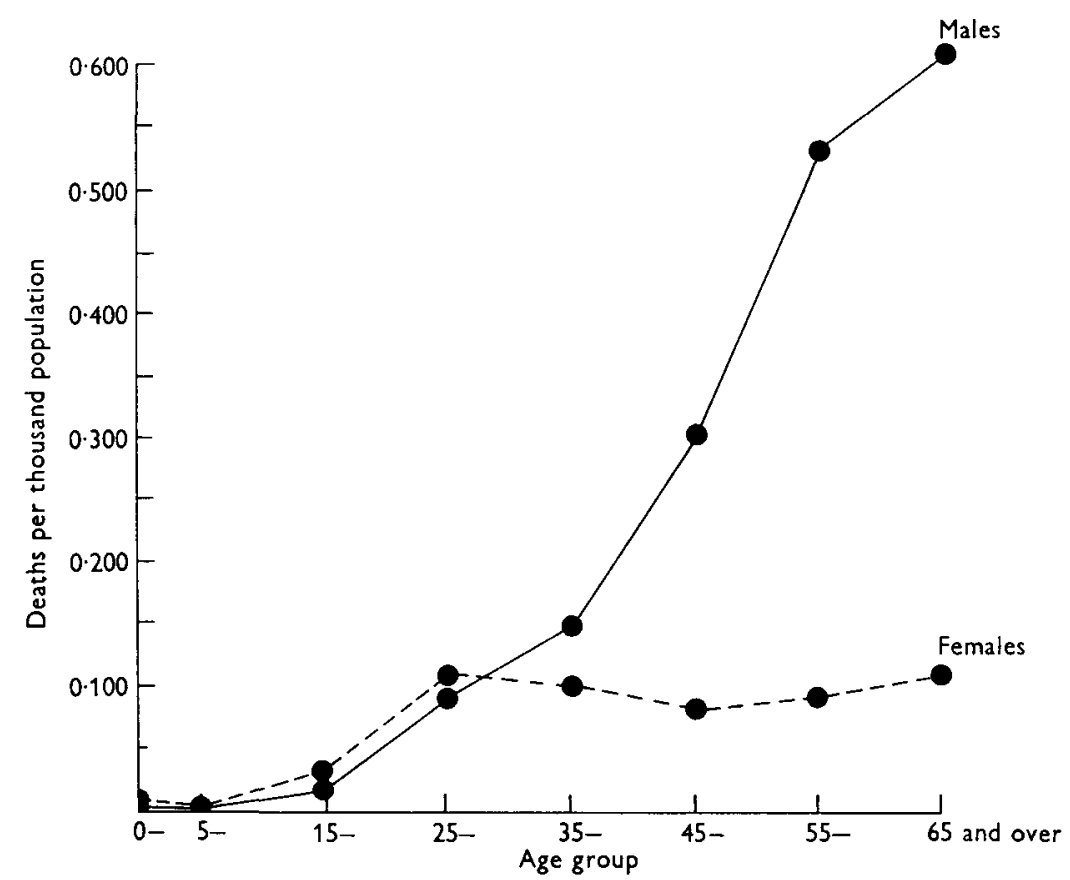

Fig. 2. Death-rates for respiratory tuberculosis, England and Wales, 1955.

ages over 65 . In 1956 the mortality rate for men over 65 was 640 per million, compared with 14 per million for men aged 20-25. For women, however, the peak of mortality has remained in the 25-34-year age group, except for a shift to the 35-44-year age group between 1891 and 1909, and to the 20-24-year age group between 1921 and 1950.

Tuberculosis mortality rates for men living in London derived from the same sources show a different pattern. In 1851-60 the peak mortality for males from phthisis (6093 per million) occurred between the ages of 45 and 54, while the peak mortality for females (4121 per million) occurred between the ages of 35 and 44 . From 1891 to 1930 peak mortality for males in both London and England and Wales occurred in the 45-54-year age group, from 1936 to 1950 in the 55-64-year age group, and since 1951 at ages over 65 . Tuberculosis rates for women living in London show that the peak of mortality in 1851-60 (4121 per million) occurred in the 35-44-year age group, and remained in this age group until 1920. A shift to younger age groups also occurred in London at this time. Finally, in recent years, effective chemotherapy has gradually obliterated the young adult peak. 
Such changes in the epidemiology of a disease suggest the operation of environmental factors that might perhaps be controlled by public health measures.

Analysis of tuberculosis mortality rates by social class, occupational groups, and urban and rural domicile shows that whereas male mortality and morbidity rates exceed female rates throughout England and Wales, the male excess is greatest in large towns and least in rural areas and among occupational groups such as farmers and their wives. Furthermore, in rural areas the pattern of male mortality most closely resembles the female pattern (McDonald, 1952).

The reasons for the shift in mortality to later age groups have been the subject of detailed studies by Frost (1939), Springett (1950), Daw (1950) and Spicer (1954), who analysed tuberculosis mortality on a cohort basis.

Springett (1950) concluded that for purely mathematical reasons, if tuberculosis rates are falling equally at all ages of cohorts, but are plotted graphically for calendar years, a fall in rate of a given rapidity may lead to a shift of the peak of a rounded or plateau type of curve, such as that for males in the years 1851-60, whereas for the same rate of improvement no shift occurs of the peak of a more sharply peaked curve, such as that for females over the same period. He pointed out however (1952) that the increasing male: female ratio shows that other influences are at work, and that the female rates have followed the cohort pattern less rigidly than have the male rates. In another paper (Springett, 1951) evidence was produced to show that much of the mortality among older men is due to reactivation of tuberculous disease acquired, but not diagnosed, in young adult life. This conclusion was supported by Lowe (1954).

Analysis of tuberculosis mortality and morbidity rates for other countries and past decades confirms the influence of urbanization as the over-riding factor in the production of an excess male mortality and morbidity (Viel, 1946, 1947; Ferrari, 1946; Ukil, 1948; Dahlberg, 1949; Yoshioka, 1953; Monk \& Terris, 1958). In some rural areas female rates have been shown to exceed male rates at all ages (Ostenfeld, Heitmann \& Neander, 1931; Stouman, 1931). Excess male mortality is clearly the corollary of excess male morbidity and its causes must be sought in a study of urban environment.

\section{INVESTIGATIONS}

In initiating a study of the causes of excess morbidity from tuberculosis in an urban environment, the most promising line of inquiry seemed to be a study of those factors already known to bear unequally on men and women, and to be more prevalent in an urban environment, viz.:

(1) The employment of men in large groups, exposing them to a risk of infection and superinfection at work, from which women over $\mathbf{4 0}$ are largely protected by marriage - a cause postulated by Dahlberg (1949) and McDonald (1952).

(2) Conditions of employment among men from which women are protected by factory legislation, e.g. the working of an excessive number of hours of overtime, night-work, and exposure to noxious dusts and fumes.

(3) The influence of social habits known to be more prevalent among men than women, and in urban than in rural groups, namely smoking (Doll \& Hill, 1952; 
Hammond \& Horn, 1954, 1958; Lowe, 1956; Edwards, 1957), alcoholism (Henderson \& Gillespie, 1956); and casual employment which involves moving from town to town, and sleeping in lodgings and lodging houses (National Assistance Board, 1955; London School of Hygiene and Tropical Medicine, 1955; Laidlaw, 1956; Sparer, 1956).

(4) The association with other illnesses known to be more prevalent in men than women, and in urban than rural surroundings, namely peptic ulceration, chronic bronchitis, and pneumonia (Doll \& Jones, 1951; Goodman, Lane \& Rampling, 1953; General Register Office, 1956; Reid, 1958).

In a study of factors influencing sex differences in mortality from respiratory tuberculosis in England and Wales, McDonald (1952) concluded that the risk of infection and superinfection at work was the most likely cause of the increasingly unfavourable mortality experience of occupied males as they grew older. Dahlberg (1949) had made similar observations.

It would be reasonable to suppose that a population of women employed to pensionable age on the same conditions as men should have higher morbidity rates than the general population of women. The only working female population of adequate size suitable for investigating the truth of this hypothesis was found to be in the Civil Service. The primary notifications for both sexes, and each 10-year age group, for the years 1951-52 were compared with the numbers of notifications in each sex and age group expected if the national notification rates for that age group prevailed. The population of established civil servants, stratified by age and sex, was supplied by the Treasury Statistician for 2 years. Details of all primary notifications of established civil servants were studied by courtesy of the Treasury Medical Department at the Treasury, the Post Office, and the Department of Inland Revenue. It was found (Table 1 ) that in female civil servants in every age group over the age of 20 fewer cases of tuberculosis occurred than would have been expected had they experienced the national morbidity rates, though this difference was not statistically significant in any age group. In particular there was no evidence of an increased incidence of tuberculosis in women over 40 as a result of their continued employment outside the home. When the investigation was confined to the clerical grades of the Civil Service alone (Table 2) the tuberculosis morbidity of women clerks was below the national average for women under the age of 45, and slightly above the national average for women over the age of 45, though not significantly so. In the clerical grades of the Civil Service the rates for men under 45 were significantly above the national figures, while the rates for men over 55 were slightly, but insignificantly, below the national average.

Comparison of tuberculosis morbidity rates in the Civil Service was made with the national rates, since Civil Service staff are distributed over both urban and rural areas, and this seemed the most appropriate comparison. Unfortunately, the population of women at risk over the age of 45, even in an organization the size of the Civil Service, is small (approximately 30,000), and the number of new cases of tuberculosis expected at national rates is very small indeed. Furthermore, the working population is not confined to an urban environment, but spread over the countryside. Therefore the Civil Service is far from being the ideal field for 
Table 1. Comparison of number of cases expected in a population of established civil servants at notification rates of England and Wales, with number observed

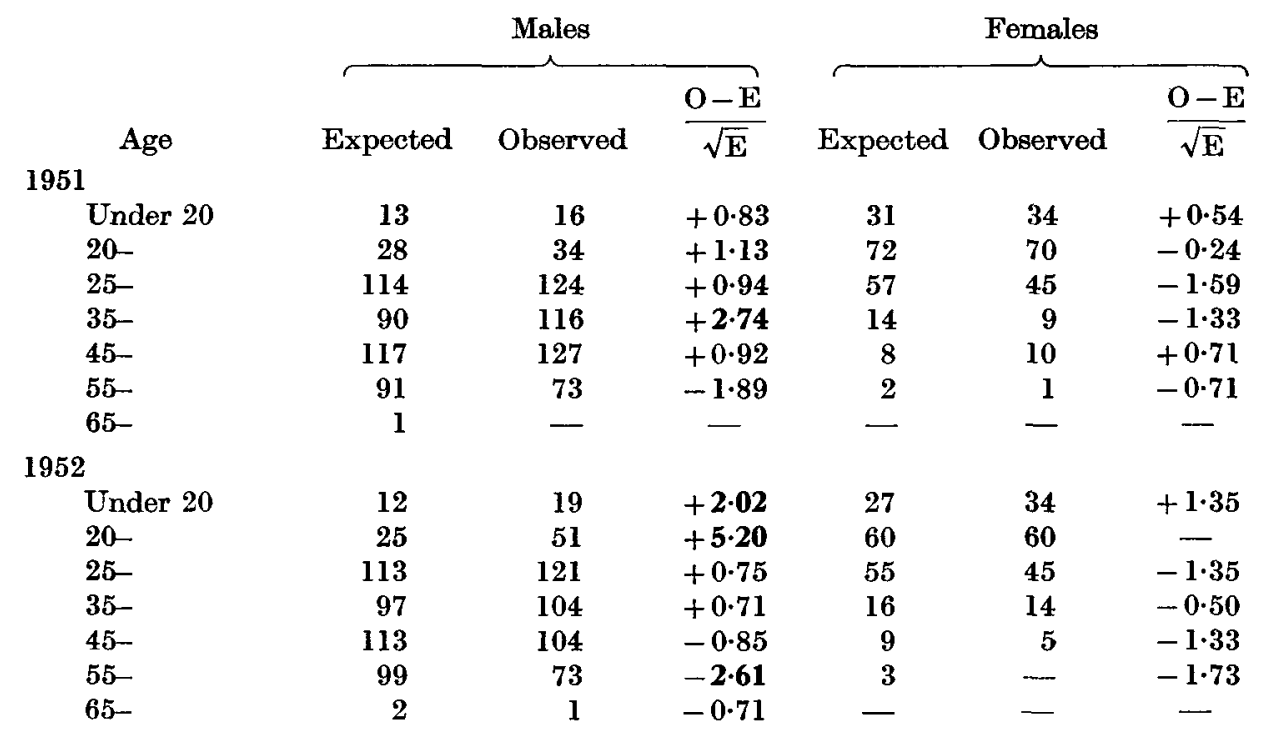

The figures in the third column headed $(\mathrm{O}-\mathrm{E}) / \sqrt{\mathrm{E}}$ indicate the amount by which the difference exceeds the standard error. Only the figures in heavy type should be considered of any significance.

Table 2. Cases observed in thsolerical grades of the Civil Service compared with cases expected at national notification rates for the years 1951 and 1952

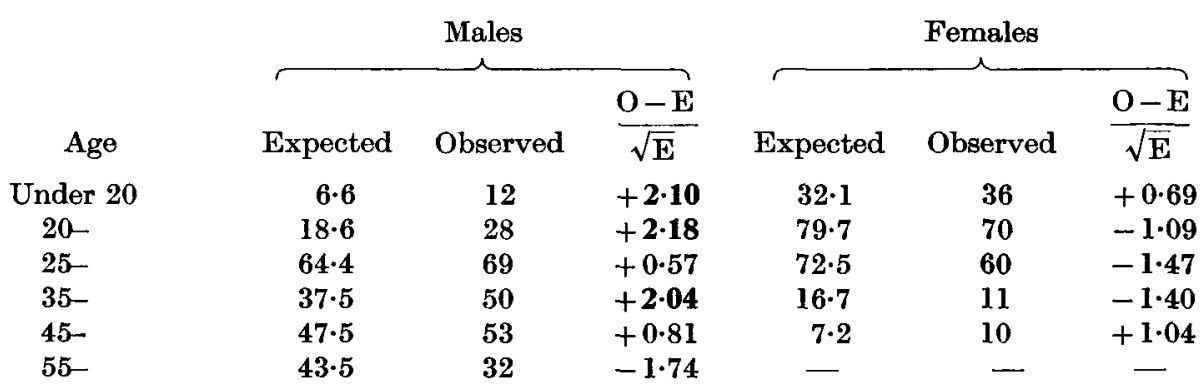

The figures in the column headed $(\mathrm{O}-\mathrm{E}) / \sqrt{\mathrm{E}}$ indicate the amount by which the difference exceeds the standard error. Only the figures in heavy type should be considered of any significance.

investigation. Efforts to obtain similar information about textile workers, and examination of the death-rates for skilled and partly skilled cotton workers obtained from the $1 \%$ sample of the 1951 Census, gave no grounds for supposing that a high rate of tuberculosis would be found among women over 40 employed in the textile industry. This part of the investigation must, however, be regarded as inconclusive, though it lends little support to the suggestion that exposure to infection and superinfection at work is wholly responsible for excess male morbidity and mortality at ages over 40 . 


\section{ENVIRONMENTAL FACTORS (OTHER THAN EXPOSURE TO INFECTION AT WORK) AMONG MEN OVER 40 IN LONDON}

Literature on urban sociology, and the Registrar-General's Reports, show that many factors long thought to affect tuberculosis morbidity are more prevalent in urban areas all over the world, and among men than among women. It was therefore decided to find out how far the male excess morbidity from tuberculosis over the age of 40 in London was associated with $(a)$ such medical ailments as peptic ulceration, gastrectomy, chronic bronchitis, and ankylosing spondylitis, (b) heavy smoking and drinking, and (c) conditions of work from which women are protected by law, such as excessive overtime work, night-work, and work with noxious processes.

\section{Methods of study}

Selection of clinics. Clinics were not drawn at random from the London area, because in many areas it would have been impossible to find a satisfactory accident and surgical service draining the same area to provide matched controls. The clinics selected therefore were those already closely associated with a large general hospital, and often situated in the hospital out-patient department. Table 3 indicates the distribution of cases in the London area.

\section{Table 3. Geographical distribution of cases of tuberculosis}

South West Metropolitan Regional Hospital Board

$\begin{array}{lrll}\text { St Helier's Hospital Group of five clinics } & 33 & \\ \text { St Thomas's Hospital (Lambeth) } & 57 & \\ \text { Westminster Clinic } & 20 & \\ \text { Battersea Clinic } & 2 & \text { Total } 112\end{array}$

North West Metropolitan Regional Hospital Board

$\begin{array}{llll}\text { Hammersmith Clinic } & 54 & \\ \text { Willesden Clinic } & 35 & \\ \text { Harrow Clinic } & 30 & \\ \text { Edgware Clinic } & 27 & \text { Total } 146\end{array}$

North East Metropolitan Regional Hospital Board

\begin{tabular}{lrll} 
Edmonton Clinic & 44 & \\
Tottenham Clinic & 2 & \\
Bethnal Green Clinic & 49 & \\
University College (Holborn) & 3 & Total 98 \\
\multicolumn{1}{r}{ South East Metropolitan Regional Hospital Board } \\
Greenwich Clinic & 38 & \\
Deptford Clinic & 6 & \\
Sidcup Clinic & 2 & \\
Lewisham Clinic & 3 & \\
Camberwell Clinic & 40 & Total 89
\end{tabular}

Selection of cases. Cases were drawn in batches from the tuberculosis register for the area (including cases not attending the clinic). All patients in the batches drawn were interviewed within a week or two of diagnosis. It will be appreciated that a proportion of the new notifications of men in this age group appearing in the 
national figures are post-mortem notifications which are not included in this investigation.

Selection of controls. Controls were drawn from the wards and out-patient departments of accident and surgical units serving the same geographical area as the register from which the notification was drawn. Controls were selected by visiting the wards and interviewing the first patient on the ward list under treatment for injury, minor orthopaedic operation, or repair of hernia, within 5 years of age of the case to be matched, and of the same social class as determined by occupation stated on the case notes, in accordance with the Registrar-General's Classification of Occupations (General Register Office, 1951). The chest of each control patient was $\mathrm{X}$-rayed to exclude undiagnosed cases of pulmonary tuberculosis among the controls.

Interviewing. All controls were selected and interviewed by the writer using a questionnaire so worded that the answer to all questions must be an unqualified 'Yes' or 'No'. The same questionnaire was used to interview all patients. Questions were designed to elicit only the simplest facts, such as the presence or absence of gastrectomy, and some relevant information was ignored in the final analysis because it was felt that the question had not been framed in a sufficiently precise form.

\section{Results}

Four hundred and forty-five newly diagnosed tuberculous men over the age of 40, and 445 paired controls matched for age ( \pm 5 years), sex, social class, and place of residence were interviewed, using the questionnaire described. The age and social class distribution are shown in Tables 4 and 5 . The results were then tabulated

Table 4. Age distribution of cases in tables of analysis

\begin{tabular}{|c|c|c|c|c|c|}
\hline \multicolumn{6}{|c|}{ (Figures represent percentages.) } \\
\hline Age distribution & 40 & 50 & $60-$ & 70 & $80-$ \\
\hline $\begin{array}{l}\text { Tables } 5-8 . \text { Whole series of } 445 \\
\text { cases }\end{array}$ & $32 \cdot 8$ & $33 \cdot 0$ & $24 \cdot 2$ & $9 \cdot 1$ & 0.9 \\
\hline $\begin{array}{l}\text { Table 12. } 229 \text { cases from an area } \\
\text { containing a lodging house }\end{array}$ & $32 \cdot 7$ & $29 \cdot 7$ & $25 \cdot 3$ & $10 \cdot 9$ & $1 \cdot 4$ \\
\hline $\begin{array}{l}\text { Table 13. } 216 \text { cases from areas } \\
\text { containing no lodging house }\end{array}$ & $32 \cdot 8$ & $37 \cdot 0$ & $23 \cdot 1$ & $6 \cdot 65$ & 0.45 \\
\hline
\end{tabular}

to show the frequency with which the factors under investigation appeared among tuberculous and control cases; and the significance of the differences between percentages was calculated (Tables 6-9). Results are tabulated separately for cases and controls in three age groups (Tables 10-12) and for cases and controls drawn from areas in which lodging houses are situated and others (Tables 13, 14).

\section{Frequency of other medical ailments (Table 6)}

From Tables 6-9 it will be seen that a large number of conditions suggested as possibly being associated with the male excess morbidity from tuberculosis in urban areas were found to be present in a significantly greater percentage of 
Table 5. Social class distribution of 445 cases and paired controls

$\begin{array}{cccccc}\text { Social class... } & \text { I } & \text { II } & \text { III } & \text { IV } & \text { V } \\ \text { Whole series, } & 5 & 28 & 263 & 56 & 93 \\ \text { Tables 6-9 } & 1 \cdot 12 \% & 6 \cdot 29 \% & 59 \cdot 10 \% & 12 \cdot 58 \% & 20 \cdot 89 \% \\ \text { Age 40- } & 3 & 3 & 85 & 20 & 25 \\ \text { Table 10 } & 2 \cdot 21 \% & 2 \cdot 21 \% & 62 \cdot 50 \% & 14 \cdot 71 \% & 18 \cdot 38 \% \\ \text { Age 50- } & 1 & 16 & 83 & 23 & 29 \\ \text { Table 11 } & 0 \cdot 66 \% & 10 \cdot 53 \% & 54 \cdot 61 \% & 15 \cdot 13 \% & 19 \cdot 08 \% \\ \text { Age 60- } & 1 & 9 & 95 & 13 & 39 \\ \text { Table 12 } & 0 \cdot 64 \% & 5 \cdot 73 \% & 60.51 \% & 8 \cdot 28 \% & 24 \cdot 84 \% \\ \text { Lodging house in area, } & 3 & 12 & 115 & 26 & 73 \\ \text { Table 13 } & 1 \cdot 31 \% & 5 \cdot 24 \% & 50 \cdot 22 \% & 11 \cdot 35 \% & 31 \cdot 88 \% \\ \text { No lodging house in area, } & 2 & 16 & 148 & 30 & 20 \\ \text { Table 14 } & 0.93 \% & 7 \cdot 41 \% & 68.52 \% & 13.89 \% & 9 \cdot 26 \%\end{array}$

tuberculous patients than controls. In Table 6 the $18 \%$ of patients with a history of peptic ulceration or its sequelae is the most striking. The $31 \%$ of tuberculous patients complaining of cough and sputum lasting 4 weeks or more in each of the past three winters before diagnosis are unfortunately a compound group consisting of cases of chronic bronchitis, plus a number of persons whose symptoms may have been due to undiagnosed chronic tuberculosis. No conclusions therefore can be drawn from these figures. Asthma and diabetes appear to be of little numerical importance as a predisposing factor in this group. Spondylitis and rheumatoid arthritis both occur too rarely to be of importance. A history of hospital admission for other conditions such as mental illness, accidents at work, other accidents, and all other illnesses, shows no significant difference between tuberculous patients and controls, suggesting that the tuberculous and control groups are reasonably well matched in other respects.

\section{Occupational history (Table 7)}

Investigation of the occupational history with particular reference to the extent of overtime working, night-work, and number of persons self-employed in small businesses, did not suggest that under present conditions in London these factors were of any importance in the aetiology of tuberculosis in men over 40. Nor was the number of persons retired or unemployed significantly in excess in the tuberculous group.

\section{Personal habits and social state (Tables 8,9 )}

Investigation of the personal habits of the tuberculous group compared with that of controls yielded some interesting figures. It became apparent at an early stage that many London men found to be tuberculous in middle life were homeless. $31 \%$ were single, widowed, or separated from their wives, and $21 \%$ were of Irish, Scots, Welsh, or other nationality, though most of these had lived in the London area for more than 10 years. $20 \%$ gave a history of living in lodgings or a hostel for 1 year or longer in the past 10 years. $24 \%$ had a history of eating a restricted diet for the past 2 years or longer; in most cases the diet was of gastric type modified 
Table 6. Medical history (445 pairs)

\begin{tabular}{|c|c|c|c|c|c|c|c|}
\hline Characteristic & $\begin{array}{l}\text { tuber- } \\
\text { culous }\end{array}$ & $\begin{array}{l}\text { No. } \\
\text { control }\end{array}$ & $\begin{array}{l}\text { tuber- } \\
\text { culous }\end{array}$ & $\begin{array}{c}\% \\
\text { control }\end{array}$ & $\begin{array}{l}\text { Diff. } \\
\%\end{array}$ & $\begin{array}{l}\text { S.E. of } \\
\text { diff. }\end{array}$ & $\frac{\text { Diff. }}{\text { s.E. }}$ \\
\hline Gastrectomy performed & 43 & 18 & $9 \cdot 66$ & $4 \cdot 04$ & $5 \cdot 62$ & $1 \cdot 69$ & $+\mathbf{3} \cdot \mathbf{3 3}$ \\
\hline $\begin{array}{l}\text { Peptic ulcer proved by perforation, } \\
\text { haemorrhage or barium meal } \\
\text { (excluding the gastrectomies above) }\end{array}$ & 40 & 23 & 8.99 & $5 \cdot 17$ & $3 \cdot 82$ & $1 \cdot 72$ & $+2 \cdot 22$ \\
\hline $\begin{array}{l}\text { Total of patients with history of } \\
\text { ulcer or gastrectomy }\end{array}$ & 83 & 41 & $18 \cdot 65$ & $9 \cdot 21$ & $9 \cdot 44$ & $2 \cdot 32$ & $+4 \cdot 07$ \\
\hline $\begin{array}{l}\text { History of cough and sputum lasting } \\
4 \text { weeks or more in each of the past } \\
\text { three winters }\end{array}$ & 138 & 77 & $31 \cdot 01$ & $17 \cdot 30$ & $13 \cdot 71$ & $2 \cdot 87$ & +4.78 \\
\hline $\begin{array}{l}\text { History of asthma in the past } 10 \\
\text { years }\end{array}$ & 16 & 19 & $3 \cdot 60$ & $4 \cdot 27$ & $0 \cdot 67$ & $1 \cdot 30$ & $-0 \cdot 52$ \\
\hline $\begin{array}{l}\text { History of shortness of breath } \\
\text { affecting work }\end{array}$ & 97 & 49 & $21 \cdot 80$ & $11 \cdot 01$ & $10 \cdot 79$ & $2 \cdot 48$ & +4.35 \\
\hline $\begin{array}{l}\text { Rheumatoid arthritis recorded in the } \\
\text { history }\end{array}$ & 4 & 1 & 0.90 & 0.22 & $0 \cdot 68$ & 0.50 & $+1 \cdot 36$ \\
\hline Spondylitis present & $\mathbf{3}$ & 1 & $0 \cdot 67$ & 0.22 & $0 \cdot 45$ & 0.44 & $+1 \cdot 02$ \\
\hline $\begin{array}{l}\text { History of mental illness requiring } \\
\text { hospital treatment and absence from } \\
\text { work }\end{array}$ & 19 & 15 & $4 \cdot 27$ & $3 \cdot 37$ & $0 \cdot 90$ & $1 \cdot 28$ & $+0 \cdot 70$ \\
\hline $\begin{array}{l}\text { Accident at work requiring hospital } \\
\text { treatment and absence from work }\end{array}$ & 78 & 94 & $17 \cdot 53$ & $21 \cdot 12$ & $3 \cdot 59$ & $2 \cdot 65$ & $-1 \cdot 35$ \\
\hline $\begin{array}{l}\text { Other accident requiring hospital } \\
\text { treatment and absence from work }\end{array}$ & 68 & 76 & $15 \cdot 28$ & $17 \cdot 08$ & $1 \cdot 80$ & $2 \cdot 47$ & $-0 \cdot 73$ \\
\hline Diabetes present & 13 & 6 & $2 \cdot 92$ & 1.35 & $1 \cdot 57$ & 0.97 & +1.62 \\
\hline $\begin{array}{l}\text { Other illnesses requiring hospital } \\
\text { treatment }\end{array}$ & 247 & 275 & $55 \cdot 51$ & $61 \cdot 80$ & $6 \cdot 29$ & $\mathbf{3} \cdot 30$ & -1.91 \\
\hline
\end{tabular}

Figures in the last column indicate the amount by which the difference exceeds the standard error. Only the figures in heavy type should be considered of any significance.

Table 7. Occupational history (445 pairs)

\begin{tabular}{|c|c|c|c|c|c|c|c|}
\hline Characteristic & $\begin{array}{l}\text { No. } \\
\text { tuber- } \\
\text { culous }\end{array}$ & $\begin{array}{l}\text { No. } \\
\text { control }\end{array}$ & $\begin{array}{l}\% \\
\% \\
\text { tuber- } \\
\text { culous }\end{array}$ & $\begin{array}{c}\% \\
\text { control }\end{array}$ & $\begin{array}{l}\text { Diff. } \\
\%\end{array}$ & $\begin{array}{l}\text { s.E. of } \\
\text { diff. }\end{array}$ & $\frac{\text { Diff. }}{\text { S.E. }}$ \\
\hline $\begin{array}{l}k \text { for a period exceeding } \\
\mathrm{s} \text { in the past } 5 \text { years }\end{array}$ & 37 & 36 & $8 \cdot 31$ & $8 \cdot 09$ & $0 \cdot 22$ & $1 \cdot 84$ & +0.12 \\
\hline $\begin{array}{l}\text { vertime exceeding } 50 \\
\text { hr. per week for } 3 \text { months or } \\
\text { the past } 2 \text { years }\end{array}$ & 132 & 118 & $29 \cdot 66$ & 26.52 & $3 \cdot 14$ & $3 \cdot 01$ & +1.04 \\
\hline $\begin{array}{l}\text { oyed for a period exceeding } \\
n \text { the past } 5\end{array}$ & 26 & 34 & $5 \cdot 84$ & $7 \cdot 64$ & $1 \cdot 80$ & $1 \cdot 68$ & $-1 \cdot 07$ \\
\hline $\begin{array}{l}\text { rker for a period exceeding } \\
\text { the past } 2 \text { years }\end{array}$ & 14 & 15 & $3 \cdot 15$ & $3 \cdot 37$ & $0 \cdot 22$ & $1 \cdot 19$ & -0.18 \\
\hline year or longer & 52 & 42 & $11 \cdot 69$ & $9 \cdot 44$ & $2 \cdot 25$ & $2 \cdot 06$ & $+1 \cdot 09$ \\
\hline
\end{tabular}

Figures in the last column indicate the amount by which the difference exceeds the standard error. 
by stomach capacity and the state of the patient's finances. Other diets were judged restricted when a meal was regularly replaced by beer, or, as in some kitchen workers, by snacks taken between orders. $38 \%$ of tuberculous patients smoked more than 20 cigarettes a day, or $4 \frac{1}{2} \mathrm{oz}$. of tobacco a week rolled as cigarettes. This was a significantly greater proportion than appeared in the control group, and the association was not unexpected in view of the findings of Lowe (1954) at Birmingham.

\section{Table 8. Personal habits during the past two years}

\begin{tabular}{|c|c|c|c|c|c|c|c|}
\hline Characteristic & $\begin{array}{l}\text { No. } \\
\text { tuber- } \\
\text { culous }\end{array}$ & $\begin{array}{l}\text { No. } \\
\text { control }\end{array}$ & $\begin{array}{c}\% \\
\text { tuber- } \\
\text { culous }\end{array}$ & $\begin{array}{c}\% \\
\text { control }\end{array}$ & $\begin{array}{l}\text { Diff. } \\
\%\end{array}$ & $\begin{array}{l}\text { S.E. of } \\
\text { diff. }\end{array}$ & $\frac{\text { Diff. }}{\text { s.t. }}$ \\
\hline $\begin{array}{l}\text { Inadequate or special diet for the } \\
\text { past } 2 \text { years or longer }\end{array}$ & 108 & 32 & $24 \cdot 27$ & $7 \cdot 19$ & $17 \cdot 08$ & $2 \cdot 44$ & $+7 \cdot 00$ \\
\hline $\begin{array}{l}\text { Twenty cigarettes or more daily for } \\
\text { the past } 2 \text { years or longer }\end{array}$ & 146 & 113 & $32-81$ & $25 \cdot 39$ & $7 \cdot 42$ & 3.04 & $+2 \cdot 44$ \\
\hline $\begin{array}{l}4 \frac{1}{2} \text { oz. of tobacco or more weekly, } \\
\text { rolled as cigarettes, for the past } \\
2 \text { years or longer }\end{array}$ & 23 & 12 & $5 \cdot 17$ & $2 \cdot 70$ & $2 \cdot 47$ & $1 \cdot 30$ & +1.90 \\
\hline $\begin{array}{l}\text { More than } 3 \text { pints of beer daily for } \\
\text { the past } 2 \text { years or longer }\end{array}$ & 57 & 16 & $12 \cdot 81$ & 3.60 & $9 \cdot 21$ & $1 \cdot 84$ & +5.00 \\
\hline $\begin{array}{l}\text { More than } 5 \mathrm{oz} \text {. of spirits daily for } \\
\text { the past } 2 \text { years or longer }\end{array}$ & 13 & 4 & $2 \cdot 92$ & $0 \cdot 90$ & $2 \cdot 02$ & 0.92 & $+2 \cdot 20$ \\
\hline $\begin{array}{l}\text { Regular heavy drinking at week-ends } \\
\text { for the past } 2 \text { years or longer }\end{array}$ & 31 & 7 & 6.97 & $1 \cdot 57$ & $5 \cdot 40$ & $1 \cdot 36$ & +3.97 \\
\hline $\begin{array}{l}\text { Hours in bed less than } 6 \text { per night for } \\
3 \text { months or more in the last } 2 \text { years }\end{array}$ & 37 & 10 & $8 \cdot 31$ & $2 \cdot 25$ & $6 \cdot 06$ & $\mathbf{1 \cdot 5 4}$ & +3.94 \\
\hline
\end{tabular}

Figures in the last column indicate the amount by which the difference exceeds the standard error. Only the figures in heavy type should be considered of any significance.

Table 9. Social state at time of interview (445 pairs)

\begin{tabular}{|c|c|c|c|c|c|c|c|}
\hline Characteristic & $\begin{array}{l}\text { No. } \\
\text { tuber- } \\
\text { culous }\end{array}$ & $\begin{array}{l}\text { No. } \\
\text { control }\end{array}$ & $\begin{array}{c}\% \\
\text { tuber- } \\
\text { culous }\end{array}$ & $\begin{array}{c}\% \\
\text { control }\end{array}$ & $\begin{array}{c}\text { Diff. } \\
\%\end{array}$ & $\begin{array}{l}\text { S.E. of } \\
\text { diff. }\end{array}$ & $\frac{\text { Diff. }}{\text { s.r. }}$ \\
\hline $\begin{array}{l}\text { Scots, Irish, Welsh, and foreign } \\
\text { nationality }\end{array}$ & 94 & 58 & $21 \cdot 12$ & $13 \cdot 03$ & $8 \cdot 09$ & $2 \cdot 52$ & $+3 \cdot 21$ \\
\hline Single, widower or divorced & 138 & 78 & $31 \cdot 00$ & $17 \cdot 53$ & $13 \cdot 47$ & $2 \cdot 87$ & +4.69 \\
\hline $\begin{array}{l}\text { Resident in lodgings } 1 \text { year or longer } \\
\text { in the past } 10 \text { years }\end{array}$ & 52 & 25 & $11 \cdot 69$ & $5 \cdot 62$ & $6 \cdot 07$ & $1 \cdot 88$ & $+3 \cdot 23$ \\
\hline $\begin{array}{l}\text { Resident in common lodging house or } \\
\text { hostel for } 1 \text { year or longer in the past }\end{array}$ & 39 & 11 & $8 \cdot 76$ & $2 \cdot 47$ & $6 \cdot 29$ & 1.54 & + \\
\hline
\end{tabular}

\section{0 years}

Figures in the last column indicate the amount by which the difference exceeds the standard error. Only the figures in heavy type should be considered of any significance.

\section{Attack rate (Tables 10-12)}

The proportion of newly diagnosed tuberculous disease in middle-aged men due to previously quiescent undiagnosed lesions has been the subject of speculation and investigation (Springett, 1951; Lowe, 1954). In this survey (Tables 10-12) cases and controls were asked whether an $\mathrm{X}$-ray of chest had been taken within the past 10 years, and if so the date and place, and the result. $61 \%$ of control patients 
claimed to have had a normal film within that period, and $33 \%$ of newly notified tuberculous patients. It was not possible to trace all these films, and in fact patients are frequently informed that their chest $\mathrm{X}$-ray is satisfactory when an inactive lesion not thought to require clinical supervision is present. One must presume therefore that many of these films may have shown inactive tuberculous infection. However, of the films traced, a surprising number showed no evidence of a tuberculous lesion, and a number of men over the age of 60 were found to have developed active sputum-positive tuberculosis within a year or two of having an apparently normal film.

Table 10. Cases and controls aged 40-49 (136 pairs)

\section{Characteristic}

Irish, Scots, Welsh or foreign nationality

Normal X-ray of chest reported to have been taken within the past 10 years

\begin{tabular}{|c|c|c|c|c|c|c|}
\hline $\begin{array}{l}\text { No. } \\
\text { tuber- } \\
\text { culous }\end{array}$ & $\begin{array}{c}\text { No. } \\
\text { control }\end{array}$ & $\begin{array}{c}\% \\
\text { tuber- } \\
\text { culous }\end{array}$ & $\begin{array}{c}\% \\
\text { control }\end{array}$ & $\begin{array}{c}\text { Diff. } \\
\%\end{array}$ & $\begin{array}{l}\text { s.E. of } \\
\text { diff. }\end{array}$ & $\frac{\text { Diff. }}{\text { s.E. }}$ \\
\hline 30 & 26 & $22 \cdot 06$ & $19 \cdot 12$ & $2 \cdot 94$ & $4 \cdot 90$ & +0.60 \\
\hline 50 & 99 & $36 \cdot 76$ & 72.79 & $36 \cdot 03$ & $6 \cdot 04$ & -5.97 \\
\hline 9 & 3 & $6 \cdot 62$ & $2 \cdot 21$ & $4 \cdot 41$ & $2 \cdot 49$ & +1.77 \\
\hline 10 & 5 & $7 \cdot 35$ & $3 \cdot 68$ & $3 \cdot 67$ & 2.77 & +1.32 \\
\hline 15 & 11 & $11 \cdot 03$ & 8.09 & $2 \cdot 94$ & 3.57 & +0.82 \\
\hline 10 & 6 & $7 \cdot 35$ & $4 \cdot 41$ & $2 \cdot 94$ & $2 \cdot 85$ & +1.03 \\
\hline 37 & 24 & $27 \cdot 21$ & $17 \cdot 65$ & $9 \cdot 56$ & $5 \cdot 06$ & $+1 \cdot 89$ \\
\hline 53 & 46 & 38.97 & $33 \cdot 82$ & $5 \cdot 15$ & $5 \cdot 83$ & +0.88 \\
\hline 23 & 5 & 16.91 & $3 \cdot 68$ & $13 \cdot 23$ & $3 \cdot 69$ & +3.59 \\
\hline 7 & 2 & $5 \cdot 15$ & 1.47 & $3 \cdot 68$ & $2 \cdot 17$ & $+1 \cdot 70$ \\
\hline 12 & 6 & $8 \cdot 82$ & $4 \cdot 41$ & $4 \cdot 41$ & 3.01 & +1.47 \\
\hline
\end{tabular}

Figures in the last column indicate the amount by which the difference exceeds the standard error. Only the figures in heavy type should be considered of any significance.

\section{Analysis by age groups (Tables 10-12)}

When all these factors were examined separately for each decade over the age of 40 , the adverse environmental influences were most obvious in the 50-59-year age group. It was noted at the time of interview that many men over 60 had found that health and finances could no longer stand up to the heavy drinking and smoking of their younger days, but since the personal habits of the last 2 years only were recorded, many men who had once been heavy drinkers were counted as nondrinkers. 


\section{Analysis by residential area (Tables 13-14)}

Approximately half the cases were derived from areas in which a lodging house was situated, and the remaining cases from areas with a more stable population. When these two groups were examined separately, the greatest differences between cases and controls were evident in the areas containing lodging houses. Heavy smoking and drinking appeared to be the most significant factors associated with notifications in the remaining areas.

Table 11. Cases and controls aged 50-59 (152 pairs)

\begin{tabular}{|c|c|c|c|c|c|c|c|}
\hline Characteristic & $\begin{array}{l}\text { No. } \\
\text { tuber- } \\
\text { culous }\end{array}$ & $\begin{array}{l}\text { No. } \\
\text { control }\end{array}$ & $\begin{array}{l}\text { \% } \\
\text { tuber- } \\
\text { culous }\end{array}$ & $\begin{array}{c}\% \\
\text { control }\end{array}$ & $\begin{array}{l}\text { Diff. } \\
\%\end{array}$ & $\begin{array}{l}\text { s.E. of } \\
\text { diff. }\end{array}$ & $\frac{\text { Diff. }}{\text { s.e. }}$ \\
\hline $\begin{array}{l}\text { Irish, Scots, Welsh or foreign } \\
\text { nationality }\end{array}$ & 36 & 9 & $23 \cdot 68$ & $5 \cdot 92$ & $17 \cdot 76$ & $4 \cdot 07$ & $+4 \cdot 36$ \\
\hline $\begin{array}{l}\text { Normal X-ray of chest reported to } \\
\text { have been taken within the past } \\
10 \text { years }\end{array}$ & 52 & 92 & $34 \cdot 21$ & $60 \cdot 53$ & $26 \cdot 32$ & $5 \cdot 73$ & $-4 \cdot 59$ \\
\hline Gastrectomy performed & 21 & 8 & $13 \cdot 82$ & $5 \cdot 26$ & $8 \cdot 56$ & $3 \cdot 37$ & +2.54 \\
\hline $\begin{array}{l}\text { Peptic ulcer proved by perforation, } \\
\text { haemorrhage or barium meal recorded } \\
\text { in the medical history }\end{array}$ & 10 & 9 & $6 \cdot 58$ & $5 \cdot 92$ & 0.66 & $2 \cdot 78$ & $+0 \cdot 24$ \\
\hline $\begin{array}{l}\text { History of living in lodgings for } \\
1 \text { year or longer in the past } 10 \text { years }\end{array}$ & 20 & 6 & $13 \cdot 16$ & $3 \cdot 95$ & $9 \cdot 21$ & $3 \cdot 21$ & $+2 \cdot 87$ \\
\hline $\begin{array}{l}\text { History of living in common lodging } \\
\text { house or hostel for } 1 \text { year or longer } \\
\text { in the past } 10 \text { years }\end{array}$ & 14 & 2 & $9 \cdot 21$ & $1 \cdot 32$ & $7 \cdot 89$ & $2 \cdot 56$ & $+3 \cdot 08$ \\
\hline Single, widower or divorced & 40 & 21 & $26 \cdot 32$ & $13 \cdot 82$ & $12 \cdot 50$ & $4 \cdot 59$ & $+2 \cdot 72$ \\
\hline $\begin{array}{l}\text { History of smoking } 20 \text { or more } \\
\text { cigarettes daily for the past } 2 \text { years } \\
\text { or longer }\end{array}$ & 64 & 45 & $42 \cdot 11$ & $29 \cdot 61$ & $12 \cdot 50$ & $5 \cdot 50$ & $+2 \cdot 27$ \\
\hline $\begin{array}{l}\text { More than } 3 \text { pints of beer daily for } \\
\text { the past } 2 \text { years or longer }\end{array}$ & 25 & 8 & $16 \cdot 45$ & $5 \cdot 26$ & $11 \cdot 19$ & $3 \cdot 57$ & $+3 \cdot 13$ \\
\hline $\begin{array}{l}\text { More than } 5 \mathrm{oz} \text {. of spirit daily for the } \\
\text { past } 2 \text { years or longer }\end{array}$ & 5 & - & $3 \cdot 29$ & - & $3 \cdot 29$ & $1 \cdot 46$ & $+2 \cdot 25$ \\
\hline $\begin{array}{l}\text { Regular heavy drinking at week- } \\
\text { ends for the past } 2 \text { years or longer }\end{array}$ & 14 & - & $9 \cdot 21$ & - & $9 \cdot 21$ & $2 \cdot 40$ & +3.84 \\
\hline
\end{tabular}

Figures in the last column indicate the amount by which the difference exceeds the standard error. Only the figures in heavy type should be considered of any significance.

\section{Lodging houses}

Several references have been made to lodging houses in which thirty-nine patients stated they had lived one year or longer in the past 10 years. Inquiry of medical officers of health showed that there are upwards of 13,000 beds for men in this type of accommodation in London, compared with something over 300 for women. It was therefore of interest to discover what proportion of new notifications of men over 40 were derived from hostels of all types. Medical officers of health kindly supplied primary notifications of men from these addresses for the years 1955 and 1956, and primary notifications by age and sex for the same area were supplied by the London County Council. From these figures it appeared that for 1956, of 
2154 males notified over the age of $15,180(8 \cdot 3 \%)$ were living in a hostel or common lodging house at the date of notification. When men over 45 were considered separately, $11 \cdot 2 \%$ of the primary notifications were derived from hostels. Such figures as it has been possible to collect from the provinces suggest that a similar situation exists in the largest provincial towns. It is probable that boarding houses of equivalent economic status would show just as high a prevalence of pulmonary tuberculosis, since men are frequently billeted three or four to a small room, and the turnover in room-mates is high.

Table 12. Cases and controls aged 60 and over (157 pairs)

\begin{tabular}{|c|c|c|c|c|c|c|c|}
\hline Characteristic & $\begin{array}{l}\text { No. } \\
\text { tuber- } \\
\text { culous }\end{array}$ & $\begin{array}{l}\text { No. } \\
\text { control }\end{array}$ & $\begin{array}{l}\% \\
\text { tuber- } \\
\text { culous }\end{array}$ & $\begin{array}{c}\% \\
\text { control }\end{array}$ & $\begin{array}{l}\text { Diff. } \\
\%\end{array}$ & $\begin{array}{l}\text { s.E. of } \\
\text { diff. }\end{array}$ & $\frac{\text { Diff. }}{\text { s.e. }}$ \\
\hline $\begin{array}{l}\text { Irish, Scots, Welsh or other } \\
\text { nationality }\end{array}$ & 28 & 23 & $17 \cdot 83$ & $14 \cdot 65$ & $3 \cdot 18$ & $4 \cdot 16$ & +0.76 \\
\hline $\begin{array}{l}\text { Normal } X \text {-ray of chest reported to } \\
\text { have been taken within the past } \\
10 \text { years }\end{array}$ & 47 & 83 & $29 \cdot 94$ & $52 \cdot 87$ & $22 \cdot 93$ & $5 \cdot 56$ & $-4 \cdot 12$ \\
\hline Gastrectomy performed & 13 & 7 & $8 \cdot 28$ & $4 \cdot 46$ & $3 \cdot 82$ & $2 \cdot 75$ & $+1 \cdot 39$ \\
\hline $\begin{array}{l}\text { Peptic ulcer proved by perforation, } \\
\text { haemorrhage or barium meal recorded } \\
\text { in medical history }\end{array}$ & 20 & 9 & $12 \cdot 74$ & $5 \cdot 73$ & $7 \cdot 01$ & $3 \cdot 27$ & $+2 \cdot 14$ \\
\hline $\begin{array}{l}\text { History of living in lodgings for } \\
1 \text { year or longer in the past } 10 \text { years }\end{array}$ & 17 & 8 & $10 \cdot 83$ & $5 \cdot 10$ & $5 \cdot 73$ & $3 \cdot 06$ & +1.87 \\
\hline $\begin{array}{l}\text { History of living in a common lodging } \\
\text { house or hostel for } 1 \text { year or longer } \\
\text { in the past } 10 \text { years }\end{array}$ & 15 & 3 & $9 \cdot 55$ & $1 \cdot 91$ & $7 \cdot 64$ & $2 \cdot 62$ & +2.92 \\
\hline Single, widower or divorced & 61 & 32 & $38 \cdot 85$ & $20 \cdot 38$ & $18 \cdot 47$ & $5 \cdot 15$ & +3.59 \\
\hline $\begin{array}{l}\text { History of smoking } 20 \text { or more } \\
\text { cigarettes daily for } 2 \text { years or longer }\end{array}$ & 29 & 22 & $18 \cdot 47$ & $14 \cdot 01$ & $4 \cdot 46$ & $4 \cdot 16$ & +1.07 \\
\hline $\begin{array}{l}\text { More than } 3 \text { pints of beer daily for } \\
\text { the past } 2 \text { years or longer }\end{array}$ & 9 & 3 & $5 \cdot 73$ & $1 \cdot 91$ & $3 \cdot 82$ & $2 \cdot 16$ & $+1 \cdot 77$ \\
\hline $\begin{array}{l}\text { More than } 5 \mathrm{oz} \text {. of spirit daily for } \\
\text { the past } 2 \text { years or longer }\end{array}$ & 1 & 2 & $0 \cdot 64$ & $1 \cdot 27$ & $0 \cdot 63$ & $\mathbf{I} \cdot 10$ & -0.57 \\
\hline $\begin{array}{l}\text { Regular heavy drinking at week- } \\
\text { ends for the past } 2 \text { years or longer }\end{array}$ & 5 & 1 & $3 \cdot 18$ & 0.64 & $2 \cdot 54$ & 1.54 & $+1 \cdot 65$ \\
\hline
\end{tabular}

Figures in the last column indicate the amount by which the difference exceeds the standard error. Only the figures in heavy type should be considered of any significance.

\section{DISCUSSION}

It has been stated that the high breakdown rate and incidence of new cases of tuberculosis among men over 40 compared with women of the same age is associated with urbanization, and has always been a characteristic of large towns in many parts of the world. Certain aspects of the urban way of life have been selected for investigation because the total number of women affected by them is known to be a small fraction of the number of men in any city. For example, there are about 300 female beds in lodging houses in London, compared with something over 13,000 male beds, and the average male prison population in 1957 was 21,508 
compared with 860 females. To complete the investigation it would be necessary to find a large population of women over 40 living the casual life of an unskilled labourer, and demonstrate an incidence of the disease similar to male rates. Since no such population exists in this country, it has not been possible to pursue the investigation along these lines. It should, however, be noted that in more primitive agricultural countries where women undertake heavy work, female mortality may exceed male mortality at all ages (League of Nations, 1931; Ukil, 1948).

Table 13. Cases and controls drawn from an area in which a working men's hostel or lodging house is situated (229 pairs)

\begin{tabular}{|c|c|c|c|c|c|c|c|}
\hline Characteristic & $\begin{array}{l}\text { No. } \\
\text { tuber- } \\
\text { culous }\end{array}$ & $\begin{array}{l}\text { No. } \\
\text { control }\end{array}$ & $\begin{array}{l}\% \\
\text { tuber- } \\
\text { culous }\end{array}$ & $\begin{array}{c}\% \\
\text { control }\end{array}$ & $\begin{array}{l}\text { Diff. } \\
\%\end{array}$ & $\begin{array}{l}\text { s.E. of } \\
\text { diff. }\end{array}$ & $\frac{\text { Diff. }}{\text { s.E. }}$ \\
\hline $\begin{array}{l}\text { Irish, Scots, Welsh or foreign } \\
\text { nationality }\end{array}$ & 68 & 37 & $29 \cdot 69$ & $16 \cdot 16$ & $13 \cdot 53$ & $3 \cdot 93$ & $+3 \cdot 44$ \\
\hline $\begin{array}{l}\text { Normal X-ray of chest reported to } \\
\text { have been taken within the past } \\
10 \text { years }\end{array}$ & 76 & 128 & $33 \cdot 19$ & $5 \overline{5} \cdot 90$ & $22 \cdot 71$ & $4 \cdot 64$ & -4.89 \\
\hline Gastrectomy performed & 28 & 10 & $12 \cdot 23$ & $4 \cdot 37$ & $7 \cdot 86$ & $2 \cdot 58$ & +3.05 \\
\hline $\begin{array}{l}\text { Peptic ulcer proved by perforation, } \\
\text { haemorrhage or barium meal recorded } \\
\text { in medical history }\end{array}$ & 26 & 13 & $11 \cdot 35$ & $5 \cdot 68$ & $5 \cdot 67$ & $2 \cdot 61$ & $+2 \cdot 17$ \\
\hline $\begin{array}{l}\text { History of living in lodgings } 1 \text { year } \\
\text { or longer in the past } 10 \text { years }\end{array}$ & 36 & 11 & $15 \cdot 72$ & $4 \cdot 80$ & 10.92 & $2 \cdot 84$ & $+3 \cdot 85$ \\
\hline $\begin{array}{l}\text { History of living in common lodging } \\
\text { house or hostel for } 1 \text { year or longer } \\
\text { in the past } 10 \text { years }\end{array}$ & 38 & 9 & 16.59 & $3 \cdot 93$ & $12 \cdot 66$ & $2 \cdot 84$ & $+4 \cdot 46$ \\
\hline Single, widower or divorced & 94 & 48 & $41 \cdot 05$ & $20 \cdot 96$ & $20 \cdot 09$ & $4 \cdot 32$ & $+4 \cdot 65$ \\
\hline $\begin{array}{l}\text { History of smoking } 20 \text { or more } \\
\text { cigarettes daily for } 2 \text { years or longer }\end{array}$ & 75 & 67 & $32 \cdot 75$ & $29 \cdot 26$ & $3 \cdot 49$ & $4 \cdot 32$ & +0.81 \\
\hline $\begin{array}{l}\text { More than } 3 \text { pints of beer daily for } \\
\text { the past } 2 \text { years or longer }\end{array}$ & 39 & 11 & $17 \cdot 03$ & $4 \cdot 80$ & $12 \cdot 23$ & $2 \cdot 91$ & $+4 \cdot 20$ \\
\hline $\begin{array}{l}\text { More than } 5 \mathrm{oz} \text {. of spirit daily for } \\
\text { the past two years or longer }\end{array}$ & 10 & 3 & $4 \cdot 37$ & $I \cdot 3 I$ & $3 \cdot 06$ & $1 \cdot 55$ & $+1 \cdot 97$ \\
\hline $\begin{array}{l}\text { Regular heavy drinking at week-ends } \\
\text { for the past } 2 \text { years or longer }\end{array}$ & 21 & 6 & $9 \cdot 17$ & $2 \cdot 62$ & 6.55 & $2 \cdot 20$ & +2.98 \\
\hline
\end{tabular}

Figures in the last column indicate the amount by which the difference exceeds the standard error. Only the figures in heavy type should be considered of any significance.

Evidence of association between the factors investigated and pulmonary tuberculosis is, of course, no evidence of causation and it is not possible from this investigation to state what proportion of the newly notified cases were suffering from disease contracted, but not diagnosed, in early adult life. Springett (1951) investigated the attack rate of tuberculosis in civil servants who had previously been X-rayed and concluded that the incidence of new disease fell off in the older age groups; his findings have usually been accepted as valid for the general population. The factors now shown to be associated with the diagnosis of tuberculosis in men over $\mathbf{4 0}$ may lead to activation of a hitherto quiescent disease or predispose to a new infection.

The nature of the association demonstrated between these multiple factors and 
the onset of pulmonary tuberculosis must remain a matter for speculation. In each case three possibilities must be considered : first, that the factor associated is a direct cause of impaired resistance to infection; secondly, that the factor under consideration, and susceptibility to tuberculosis, are independently associated with a third factor, e.g. somatotype or blood group; or thirdly, that both pulmonary tuberculosis and the associated factor occur most commonly in persons who habitually associate with infectious cases of tuberculosis.

Table 14. Cases and controls drawn from an area in which no hostel or lodging house is situated (216 pairs)

\begin{tabular}{|c|c|c|c|c|c|c|c|}
\hline Characteristic & $\begin{array}{l}\text { No. } \\
\text { tuber- } \\
\text { culous }\end{array}$ & $\begin{array}{l}\text { No. } \\
\text { control }\end{array}$ & $\begin{array}{l}\% \\
\text { tuber- } \\
\text { eulous }\end{array}$ & $\begin{array}{c}\% \\
\text { control }\end{array}$ & $\begin{array}{l}\text { Diff. } \\
\%\end{array}$ & $\begin{array}{l}\text { S.E. of } \\
\text { diff. }\end{array}$ & $\frac{\text { Diff. }}{\text { S.E. }}$ \\
\hline $\begin{array}{l}\text { Irish, Scots, Welsh or foreign } \\
\text { nationality }\end{array}$ & 26 & 21 & $12 \cdot 04$ & $9 \cdot 72$ & $2 \cdot 32$ & $2 \cdot 99$ & $+0 \cdot 78$ \\
\hline $\begin{array}{l}\text { Normal X-ray of chest reported to } \\
\text { have been taken within the past } \\
10 \text { years }\end{array}$ & 73 & 146 & $33 \cdot 80$ & $67 \cdot 59$ & $33 \cdot 79$ & $4 \cdot 81$ & $-7 \cdot 02$ \\
\hline Gastrectomy performed & 15 & 8 & $6 \cdot 94$ & $3 \cdot 70$ & $3 \cdot 24$ & $2 \cdot 16$ & $+1 \cdot 50$ \\
\hline $\begin{array}{l}\text { Peptic ulcer proved by perforation, } \\
\text { haemorrhage or barium meal recorded } \\
\text { in the medical history }\end{array}$ & 14 & 10 & $6 \cdot 48$ & $4 \cdot 63$ & 1.85 & $2 \cdot 21$ & $+0 \cdot 84$ \\
\hline $\begin{array}{l}\text { History of living in lodgings for } \\
1 \text { year or longer in the past } 10 \text { years }\end{array}$ & 16 & 14 & $7 \cdot 41$ & $6 \cdot 48$ & 0.93 & $2 \cdot 45$ & +0.38 \\
\hline $\begin{array}{l}\text { History of living in cornmon lodging } \\
\text { house or hostel for } 1 \text { year or longer } \\
\text { in the past } 10 \text { years }\end{array}$ & 1 & 2 & $0 \cdot 46$ & 0.93 & $0 \cdot 47$ & $0 \cdot 80$ & $-0 \cdot 59$ \\
\hline Single, widower or divorced & 44 & 30 & $20 \cdot 37$ & $13 \cdot 89$ & $6 \cdot 48$ & $3 \cdot 63$ & $+1 \cdot 79$ \\
\hline $\begin{array}{l}\text { History of smoking } 20 \text { or more } \\
\text { cigarettes daily for the past } 2 \text { years } \\
\text { or longer }\end{array}$ & 71 & 46 & $32 \cdot 87$ & $21 \cdot 30$ & $11 \cdot 57$ & $4 \cdot 28$ & $+2 \cdot 71$ \\
\hline $\begin{array}{l}\text { More than } 3 \text { pints of beer daily for } \\
\text { the past } 2 \text { years or longer }\end{array}$ & 18 & 5 & $8 \cdot 33$ & $2 \cdot 31$ & $6 \cdot 02$ & $2 \cdot 16$ & $+2 \cdot 79$ \\
\hline $\begin{array}{l}\text { More than } 5 \mathrm{oz} \text {. of spirit daily for the } \\
\text { past } 2 \text { years or longer }\end{array}$ & 3 & 1 & $1 \cdot 39$ & $0 \cdot 46$ & 0.93 & 0.92 & +0.10 \\
\hline $\begin{array}{l}\text { Regular heavy week-end drinking for } \\
\text { the past } 2 \text { years or longer }\end{array}$ & 10 & 1 & $4 \cdot 63$ & $0 \cdot 46$ & $4 \cdot 17$ & 1.52 & +2.75 \\
\hline
\end{tabular}

Figures in the last column indicate the amount by which the difference exceeds the standard error. Only the figures in heavy type should be considered of any significance.

The nature of the association between peptic ulceration, gastrectomy and tuberculosis has been the subject of considerable debate. The more obvious assumption that tuberculous infection follows the nutritional disturbance (Anderson, Gunn \& Watt, 1955; Thorn, Brookes \& Waterhouse, 1956) is difficult to reconcile with reports that as many cases of peptic ulcer develop after tuberculosis as antedate the diagnosis (Kissen, 1958). Reports that tuberculosis developed in postgastrectomy patients who failed to regain their normal weight after operation have not been confirmed by all other workers (Steel \& Johnston, 1956). It is probable that both conditions occur more commonly in persons who can be classified in some other way, e.g. ectomorphy, though the variable differences between the sexes could not be explained in anthropometrical terms. A larger proportion 
of male ectomorphs might be exposed to the stressful situations that precipitate breakdown (Kissen, 1958), or gravitate to occupations which expose them to a greater risk of infection. No evidence of occupational stress was detected in this investigation.

Berry \& Nash (1955) found that 'phthisis destined' normal males were significantly leaner than their matched controls attending a London Mass X-ray Unit, and that this leanness was not wholly attributable to a preponderance of ectomorphs among them. It might have been due to an excess of peptic ulcer cases among the 'phthisis destined' normal males, or even to dissimilar smoking habits in the two groups.

Karvonen, Orma, Keys, Fidanza \& Brozek (1959), investigating associations between cigarette smoking, serum cholesterol, blood pressure and body fatness, found some evidence that smokers are a little leaner than matched controls, while Lowe (1956), who investigated the smoking habits of tuberculous patients and controls in Birmingham, suggested that smoking may account for a considerable part of the excessive male mortality in middle and late life. The precise nature of the association between smoking habits and the onset of pulmonary tuberculosis, however, remains speculative. It is tempting to assume that the bronchitis associated with heavy cigarette smoking leads to activation of tuberculous disease that might otherwise have remained undetected, but heavy cigarette smoking is frequently associated with other social habits such as heavy drinking, irregular meals, and insufficient sleep, that appear equally deleterious.

Serious consideration must be given to the possibility that the association between smoking, alcoholism, irregular meals and tuberculosis is no more than a reflexion of the fact that persons with such habits have spent a considerable amount of their leisure time in public houses and cheap lodgings associating with untreatable tuberculous patients, since patients who will not tolerate sanatorium discipline invariably gravitate to such surroundings.

Fourestier (1958), studying deaths from tuberculosis in Montreuil, pointed out that $92 \%$ were manual labourers, $30 \%$ alcoholics, and $20 \%$ had undergone gastrectomy. Anderson (1956), reviewing tuberculosis figures for the United States, noted that tuberculosis death-rates for white males are much higher for single, widowed, and divorced people than for married persons. Sparer (1956) noted the preponderance of first-generation immigrants, alcoholics, divorced, separated, and socially insecure persons among tuberculous patients.

There is no doubt that the casual workers of an urbanized community are one of the principal reservoirs of tuberculous infection in large towns, and that no urban community has seriously tackled this problem to date. There is no comparable female population, and few women have much to do with these men. These casual workers remain a danger to their work-mates, room-mates, and drinking companions. Persons discharged from mental hospitals and prisons mix freely in this population, and tuberculosis prevalence rates are known to be high in both groups in America (Hiscock, 1955). No reliable information is available for this country, since Mass Radiography, when attempted, is on a voluntary basis.

It is clearly unprofitable to attempt to influence the social habits of this section 
of the community. Much could be achieved, however, if the high risk groups were clearly defined, and a determined effort made to diagnose infectious cases, e.g. on change of employment, on immigration, or while serving prison sentences. An $\mathrm{X}$-ray of the chest should surely be an integral part of any routine medical examination of immigrants, prisoners, food handlers, and similar categories of persons.

Taking all the evidence into consideration it would appear that bad personal hygiene, associated especially with heavy smoking and drinking, and residence in lodging houses - conditions that are met with much less commonly in womenpredispose to the development of tuberculosis in the male. Moving frequently from one crowded lodging to another almost certainly exposes such men to a high risk of tuberculous infection, and this, combined with the other predisposing causes mentioned, is probably sufficient to explain the big difference that exists between the incidence of tuberculosis in urban men and women in the higher age groups.

\section{SUMMARY}

1. A review of the few studies so far made on the high mortality from tuberculosis among elderly men, and a consideration of the available statistics, indicate that urbanization is one of the principal factors responsible.

2. In the present inquiry, which was confined to London, 445 newly diagnosed cases of tuberculosis in men over 40 , together with the same number of paired controls, were studied by means of a questionnaire and of personal interview.

3. It was found that the tuberculous patients differed significantly from the controls in the following characteristics; Scots, Irish, Welsh, or foreign nationality; single, widower or divorced; resident in common lodging houses or hostels; inadequate or special diet; history of gastrectomy; a winter cough; shortness of breath; insufficient sleep; and heavy drinking and smoking. On the other hand, overtime or night work, diabetes, rheumatoid arthritis, asthma, and mental illness were distributed fairly evenly in the two groups.

4. Unfortunately no group of elderly women exists in this country living under the same sort of conditions as the elderly men studied here, so that it was impossible to determine how far the various factors considered were responsible for the high rate of late adult male tuberculosis. A study, however, of a population of established civil servants living under ordinary conditions revealed little difference between the observed rates of tuberculosis and those expected on the basis of national notification figures for men and women in the older age groups.

5. It appears that a low standard of personal hygiene, associated especially with heavy smoking and drinking and residence in lodging houses, predispose to the development of tuberculosis in the elderly male. Part of the evil effect of living in common lodging houses in particular may be due to the increased risk of exposure to tuberculous infection that it entails.

6. It is tentatively concluded that the casual workers of an urbanized community are one of the principal reservoirs of tuberculous infection in large towns, and since there is no numerically comparable female population, this group, and its immediate male contacts, account in large measure for the difference between the male and female tuberculosis rates in the older age groups. 
This work was initiated during the tenure of a Prophit Scholarship of the Royal College of Physicians, and completed with the aid of a grant from the Medical Research Council.

I am indebted to members of the Prophit Committee of the Royal College of Physicians for their support and encouragement, and most particularly to Dr G. S. Wilson, Director of the Public Health Laboratory Service, under whose guidance the work was carried out. Figures relating to the incidence of tuberculosis in the Civil Service are published by kind permission of Dr W. E. Chiesman, Treasury Medical Adviser, and Dr M. C. W. Long, Dr J. W. Parks, and Dr H. Stannus Stannus, whose departmental records were used to compute the figures.

I am greatly indebted to the consultants and staff of the seventeen chest clinics who co-operated in the investigation, for their interest and help in tracing patients, and to the medical superintendents of numerous sanatoria and chest hospitals, and to the surgeons who permitted me to interview patients under their care as controls.

I should like also to acknowledge the assistance received from the medical officers of health of the metropolitan boroughs who kept me informed of notifications from lodging houses in their areas, and supplied information about the accommodation.

\section{REFERENCES}

Anderson, C. D., Gunn, R. T. S. \& WatT, J. K. (1955). Brit. med. J. i, 508.

Anderson, R. J. (1956). Publ. Hlth Rep., Wash., 71, 194.

Berry, W. T. C. \& Nash, F. A. (1955). Tubercle, Lond., 36, 164.

DamlBerg, G. (1949). Brit. J. soc. Med. 3, 220.

DAw, R. H. (1950). J. Inst. Actu. 76, 143.

Doul, R. \& HILL, A. B. (1952). Brit. med. J. ii, 1271.

Doll, R. \& Jones, F. A. (1951). Spec. Rep. Ser., med. Res. Coun., Lond., no. 276.

EDWARDS, J. H. (1957). Brit. J. prev. soc. Med. 11, 10.

Ferrari, S. M. (1946). Rev. chil. Hig. 8, 241.

Fourestier, M. (1958). Pr. méd. 66, 599.

Frost, W. H. (1939). Amer. J. Hyg. (Sect. A), 30, 91.

General Register OfFice (1951). Classification of Occupations, 1950. London: H.M. Stationery Office.

General Register OfFICE (1956). Registrar-General's Statistical Review of England and Wales. 1953 Text Volume-Medical. London: H.M. Stationery Office.

Goodman, N., Lane, R. E. \& Ramplng, S. B. (1953). Brit. med. J. ii, 237.

Hammond, E. C. \& Horn, D. (1954). J. Amer. med. Ass. 155, 1316.

Hammond, E. C. \& Horn, D. (1958). J. Amer. med. Ass. 166, 1159, 1294.

Henderson, D. \& Gillespie, R. D. (1956). A Text-book of Psychiatry, 8th ed. p. 57. Oxford University Press.

Hiscock, I. (1955). Proc. R. Soc. Med. 48, 1001.

Karvonen, M., Orma, E., Keys, A., Fidanza, F. \& Brozek, J. (1959). Lancet, i, 492.

KIssen, D. M. (1958). Emotional Factors in Pulmonary Tuberculosis. London: Tavistock Publications.

LatDlaw, S. (1956). Glasgow Common Lodging Houses and the People Living in Them. City of Glasgow Corporation.

League of Nations (1931). Epidem. rep. L.o.N. 10, 89.

Logan, W. P. D. \& Benjamin, B. (1957). Tuberculosis Statistics for England and Wales, 1938-1955. General Register Office, Studies on Medical and Public Health Subjects, no. 10. London: H.M. Stationery Office.

London School of Hyghene \& Tropical Medicine (1955). Report of study group on common lodging houses. Unpublished. 
Lowe, C. R. (1954). Brit. J. prev. soc. Med. 8, 91.

Lowe, C. R. (1956). Brit. med. J. ii, 1081.

MCDonald, J. C. (1952). Brit. J. soc. Med. 6, 259.

Ministry of Health (1958). Report. Part II. On the State of Public Health, being the Annual Report of the Chief Medical Officer, 1957, p. 102. London: H.M. Stationery Office.

Monk, M. A. \& Terris, M. (1958). Amer. J. publ. Hlth, 48, 1020.

Natronal Assistance Board (1955). Report for 1954, p. 23. London: H.M. Stationery Office.

OSTENFELd, HETTMANN \& NeaNder (1931). Tuberculosis in Denmark, Norway and Sweden. League of Nations Publication. III. Health, Official no. C.H. 957. Geneva: World Peace Foundation.

REID, D. D. (1958). Lancet, i, 1237.

SPARER, P. J. (ed.) (1956). Personality, Stress and Tuberculosis. New York: International Universities Press.

SPICER, C. C. (1954). J. Hyg., Camb., 52, 361.

SPRINGETT, V. H. (1950). J. Hyg., Camb., 48, 361.

SPRINGETT, V. H. (1951). Brit. med. J. ii, 144.

SPRTNGETT, V. H. (1952). Lancet, i, 521, 575.

SteeL, S. J. \& Johnston, R. N. (1956). Brit. J. Tuberc. 50, 233.

Stouman, K. (1931). Mon. epidem. Rep. Hlth Sect. L.o.N. 10, 175, 219.

Thorn, P. A., Brookes, V. S. \& WATERHouse, J. A. H. (1956). Brit. med. J. i, 603.

UkII, A. C. (1948). Proceedings of the 4th Intermational Congress on Tropical Medicine and Malaria, 2, 1503. Washington, D.C.

VIEL, B. (1946). Rev. méd. Chile, 74, 754.

VIEL, B. (1947). Bol. Ofic. sanit. pan.-amer. 26, 422.

YosmiokA, H. (1953). Yokohama med. Bull. 4, 11.

(MS. received for publication 7. v. 59.) 